\title{
Nigella sativa: A Traditional Remedy for the Prevention of Non- Communicable and Communicable Diseases
}

Mohammad Asadul Habib*, Monia Afroze, Mohammad Farhan Islam, Mohammad Sajid, Akibul Islam Chowdhury, Nadim Ahmed

Department of Food Technology and Nutrition Science, Noakhali Science and Technology University, Sonapur-3814, Bangladesh

DOI: $10.36348 /$ sijtcm.2020.v03i07.004 | Received: 10.07.2020 | Accepted: 18.07 .2020 | Published: 25.07 .2020

*Corresponding author: Mohammad Asadul Habib

\section{Abstract}

For decades, Nigella sativa has been used as herbal medicine. Thymoquinone is a main ingredient isolated from Nigella sativa and has wide range of pharmacological activities, such as protection from oxidative stress, inflammation and infections. This is also suggested that most of the therapeutic effects of Nigella sativa are because of the presence of thymoquinone that's the most bioactive constituent of the Nigella sativa. The crude and thymoquinone extracted from its seeds and oil are effective against non-communicable diseases (hypertension, diabetes, cardiovascular disease, obesity, cancer, etc.) and communicable diseases (malaria, AIDS, hepatitis C virus, fungal, viral, and parasitic infections etc.). The literature studies were preliminary and scanty; however the results revealed that Nigella sativa (black seed) plants have a possible therapeutic impact for wide range diseases. Such results are encouraging for the incorporation of those plants in treatment of both communicable and non-communicable diseases.

Keywords: Traditional medicine, Nigella sativa, Thymoquinone, Non-communicable diseases, Communicable diseases.

Copyright @ 2020: This is an open-access article distributed under the terms of the Creative Commons Attribution license which permits unrestricted use, distribution, and reproduction in any medium for non-commercial use (NonCommercial, or CC-BY-NC) provided the original author and source are credited.

\section{INTRODUCTION}

Plants are natural factories for the production of chemical compounds, many of which are used to promote health and fight diseases and some of them are marketed as food or herbal medicines [1]. Various herbal plants are being used for treatment of various ailments since ancient time. In the modern world, herbal plants are still receiving considerable attention as indicated by the annual growth of the herbal plants based industry in developed countries that is growing at rate of 7-15\% annually [2]. Among various medicinal plants, Nigella sativa (Family Ranunculaceae) is emerging as a miracle herb with a rich historical and religious background since many researches revealed its wide spectrum of pharmacological potential [3]. Among Muslims, it is considered as one of the greatest forms of healing medicine available due to it was mentioned that black seed is the remedy for all diseases except death in one of the Prophetic hadith. It is also recommended for use on regular basis in Tibb-e-Nabwi (Prophetic Medicine) [4]. Nigella sativa has been widely used from the past to the present for various purposes, including as a painkiller, and for anthelmintic, as an appetizer, and for carminative, sudorific, digestive, diuretic, emmenagogue, guaiacol, antifebrile, galactagouge and cathartic uses. To decrease asthenia and depression, and to increase body resistance, Nigella sativa can be used [5]. The seeds of Nigella sativa are mainly used for medicinal purposes and could be used as food spice, condiment and nutritional supplements as well due to their bitter peppery taste and characteristic aroma [6]. The seeds of Nigella sativa are used as a common spice in Indian and extensively in Middle Eastern cuisines due to its pungent bitter taste and aroma. The dry-roasted nigella seeds add nice flavor in curries, vegetables, and pulses. Black seeds are also used as a flavoring agent in breads and pickles because it has very low level of toxicity [10]. It is also used as an ingredient of the spice mixture (panchphoron) and also independently of many recipes in Bengali cuisine. Cumin was traditionally used as a preservative in mummification in the ancient Egyptian civilization [7]. It has also been highlighted that the active substances of Nigella sativa known as thymoquinone have antibacterial, antifungal, antidiabetic, immunomodulator, anti-inflammatory, analgesic, antiviral, antioxidant, anticonvulsant, antihypertensive, anticancer and antihyperlipidemic effects [8]. Traditionally, asthma, diabetes, hypertension, fever, inflammation, bronchitis, dizziness, rheumatism, skin disorders, and gastrointestinal disturbances are treated by using the Nigella sativa seeds. It is also used as a 
liver tonic, digestive, antidiarrhoeal, emmenagogue, and to control parasitic infections and boost immune system [9]. Most of the therapeutic properties of this plant are due to the presence of thymoquinone which is a major active chemical component of the essential oil.

\section{Morphology of the Nigella sativa plant}

Nigella sativa is an annual phanerogam which grows to 20-90 cm tall, with finely divided leaves, the leaf segments narrowly linear to threadlike. The flowers are delicate, and typically colored white, yellow, pink, pale blue, or pale purple, with 5-10 petals. The fruit is also an oversized and inflated capsule composed of 3-7 united follicles, each containing numerous seeds $[9$, 11].
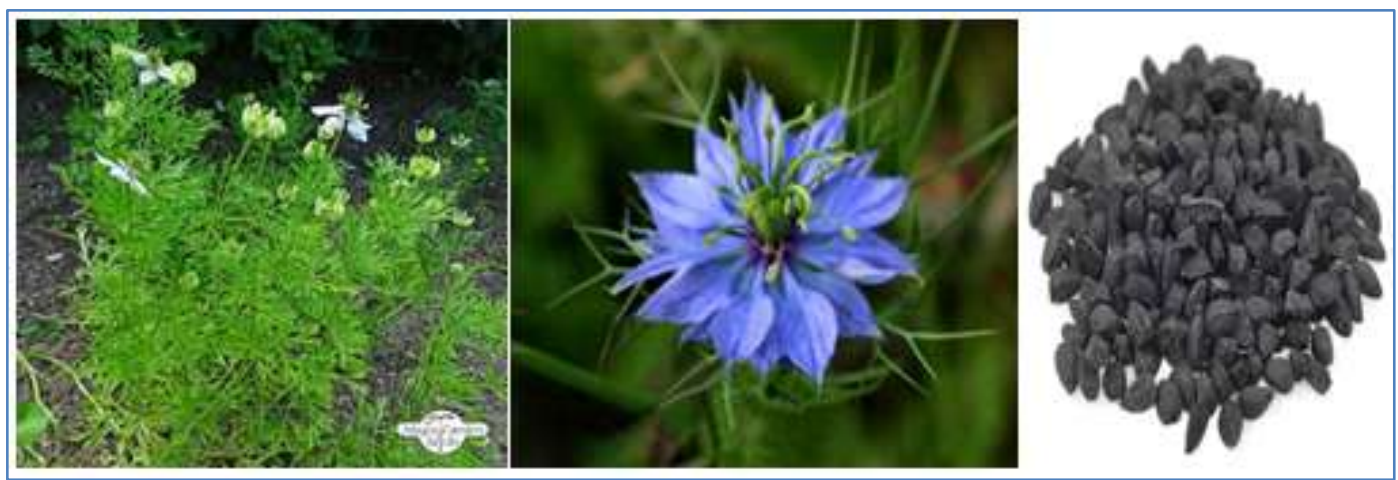

Fig-1: Nigella sativa (plant, flower and seeds) collected from internet

\section{Chemical composition of Nigella sativa}

So far several active compounds are isolated, detected, and reported in various Nigella sativa varieties. The foremost crucial active chemical compounds are thymoquinone $(30 \%-48 \%)$, thymohydroquinone, dithymoquinone, p-cymene (7\% $15 \%)$, carvacrol $(6 \%-12 \%)$, 4-terpineol $(2 \%-7 \%)$, tanethol $(1 \%-4 \%)$, sesquiterpenelongifolene (1\%-8\%), $\alpha$-pinene and thymol etc. Nigella sativa also contain trace amounts of some other compounds. Seeds contain two distinct sorts of alkaloids, i.e. isoquinolin alkaloids, e.g. nigellicimine and nigellicimine-N-oxide, and alkaloids containing nigellidine and nigellicine, pyrazol alkaloids or indazole ring bearing alkaloids $[12,13]$.

\section{BENEFITS OF Nigella sativa FOR TREATING MOST NON COMMUNICABLE DISEASES \\ Cardiovascular diseases}

The natural plant-based products play an important role in preventing cardiotoxicity and cardiorelated complications[14]. Cardiovascular disease (CVD) considered a major public health concern, is one of the world's leading causes of death. Many researchers develop many new approaches for its prevention and treatment. Changes in lifestyle and obesity are considered as major risk factors for increasing the incidence of cardiovascular disease. Other contributing factors related to cardiovascular disease are Hypertension, atherosclerosis, high cholesterol levels, and other metabolic conditions [15]. A research's findings showed that administration of Nigella sativa oil had a significant role in the normalization of physiological parameters, restored the histological structure and decreased the cardiovascular cyclooxygenase- 2 expression compared to lead group whose objective was to assess the cardioprotective effect of Nigella sativa oil on lead-induced cardiovascular toxicity and the [16]. Another study found that blood pressure in spontaneously hypertensive rats similar to nipedipine rats could be decreased by the Nigella sativa crude extract [17]. Serum cholesterol levels of the body can also be lowered by the seed treatment of Nigella sativa [18]. Besides, the aqueous extracts of Nigella sativa induced a substantial decrease in heart rate and contractility of isolated heart cells in guinea pigs [19]. A defense mechanism of the body on cisplatin-induced reduction in leukocyte and hemoglobin can be produced the extract of Nigella sativa seeds [20]. Thymoquinone, an active chemical component of Nigella sativa, has also positive effect on reducing blood cholesterol levels, triglycerides, high-density lipoproteins (HDL), and lowdensity lipoproteins (LDL) in albino rats and also has effects of hypocholesterolaemia, in addition to its ability to minimize triglyceride and LDL effects [21]. Controversial findings were also reported regarding Nigella sativa's cardiovascular actions or its active ingredients. Several studies have shown no effect of Nigella sativa on blood pressure rates in animals or humans, whereas others have shown a dose-dependent reduction in blood pressure and heart rate in normal or spontaneously hypertensive rats [17, 22, 23].

\section{Hypertension}

Hypertension, a common non-communicable disease is a key risk factor other disease like heart disease, stroke, and renal insufficiency, and is one of the most important human health issues now-a-days $[24,25]$. For treating hypertension, various groups of antihypertensive medications are currently available such as angiotensin-converting enzyme inhibitors, angiotensin II receptor blockers, calcium channel 
blockers, and thiazide-type diuretics [26]. But traditionally hypertension can be treated by Nigella sativa with many clinical advantages. Various preclinical research and clinical trials have suggested Nigella sativa as antioxidants and diuretic agents, and its role in decreasing sympathetic activity, lowering lipids, increasing the production of nitric oxides to prevent arterial stiffness, decreasing appetite and many others, all leading to its possible use as an antihypertensive agent [14, 27, 28]. In studies of humans and animals, it has been reported that blood pressure and hypertension are reduced by treating with Nigella sativa and its active component thymoquinone through various mechanisms such as antioxidant properties, calcium-channel blockage, and diuretic and hypotensive (heartbeat relieving) functions [29, 30]. Earlier research suggested that volatile oil and thymoquinone both decreased blood pressure and heart rate [23]. A significant study concluded that daily application Nigella sativa seed extract for 2 months in patients with mild hypertension may reduce blood pressure [31] for the potential role of Nigella sativa in hypertension and oxidative stress management [32].

\section{Obesity}

Obesity produces a variety of complications like insulin resistance, diabetes, hypertension, and dyslipidemia that eventually raises the risk of cardiovascular disease. For that reasons, it has been termed the "disease of diseases" [33-35]. Obesity is one of the most major public health issues in both young and older worldwide. In recent years, many alternative treatments for overweight/obesity have been introduced and the use of herbal supplements among the complementary diet-based is one of them [36]. Nigella sativa and its active ingredient thymoquinone have been used as a herbal treatment for obesity because of its anti-obesity effects and other positive effects on cardiovascular disease, cancer, insulin sensitivity, and immune-modular effects [29, 37]. Although weight loss may occur in individuals, Nigella sativa may improve the lipid profile and blood glucose levels in individuals with diabetes mellitus after weight loss depending on decreases in insulin resistance [38]. In a single doubleblind randomized controlled trial, it was noticed that body weight was reduced including in the waist and hip circumference of individuals after giving $3 \mathrm{~g} / \mathrm{day}$ Nigella sativa powder for 3 months among fifty obese men [39]. Nevertheless Nigella sativa provided to normal-weight individuals did not induce a major shift in body weight [40]. It is suspected that the consumption of Nigella sativa may be more effective against obesity if used in large quantities over a long period of time [28].

\section{Diabetes}

Diabetes a kind of metabolic disorder caused by an elevated blood glucose level causes a steady reduction in the execution of various body organs, eye, nerves, kidney, veins, and heart [41]. It has been shown that Nigella sativa and its active component thymoquinone have beneficial effects in diabetics through regulating blood glucose levels and lipid profiles [42]. Although the molecular mechanism of thymoquinone on insulin secretion has not been fully clarified, thymoquinone is reported to cause increased glucose use by increasing serum concentration, decreasing high serum glucose levels, and decreasing blood glucose by preventing gluconeogenesis [42-44]. Nigella sativa controls the blood glucose through its extrapancreatic actions, mainly inhibition of hepatic gluconeogenesis [45, 46]. Gluconeogenesis which contributes to diabetic hyperglycemia may be reduced by Nigella sativa. Reduction of the expression of gluconeogenic enzymes (glucose 6-phosphatase and fructose 1, 6-biphosphatase) and hepatic glucose production can be occurred by the active component of Nigella sativa (thymoquinone). One analysis showed that liquid consumption of Nigella sativa extract increases the synthesis of glucose and eliminates a glucose transporter in diabetic rats. Another possible mechanism of action is that components made of polyphenol can suppress the properties of transporting glucose absorption [42]. In a interventional study, administration of $2 \mathrm{~g} /$ day Nigella sativa powder for one year among type-2-DM patients found that the values of HbA1c had been significantly decreased in the intervention group [47]. In another study, it was found that Nigella sativa were expected to be mediated by extrapancreatic actions instead of induced insulin release [48]. A recent clinical trial on human showed that intake of $1 \mathrm{~g}$ of Nigella sativa seeds orally twice daily might decline in blood glucose levels after two weeks [49].

\section{Cancer}

Cancer is considered as the second most common cause of death after myocardial infarction [50]. Many people suffer from numerous types of cancer including blood cancer, breast cancer, colon cancer, hepatic cancer, skin cancer, lung cancer, and cancer of the prostate. Therefore, the scientists tried to treat various cancer forms with black seeds on patients representing a positive findings [51]. Nigella sativa and its active ingredient thymoquinone exhibits anticancer activity which kills cancer cells and prevents genetic changes in normal cells [52]. Thymoquinone has antioxidant, anticancer, and antimutagenic properties. The antioxidant properties of Nigella sativa and thymoquinone enhance antioxidant enzyme activities such as superoxide, dismutase, catalase, and glutathione peroxidase. Antioxidant enzymes reduce oxidative stress which plays an effective role in the formation and development of various types of cancer [53-55]. Nigella sativa's potential as an anti-cancer agent was first documented [56]. Thymoquinone potentiates its antitumor activity and decreases cisplatin-induced nephrotoxicity in rodents [57]. Supplementation of Nigella sativa seed and its extract exhibited cytotoxicity to lung sarcoma cells [58]. Thymoquinone had 
significant anticancer activity against numbers of lung cancer cells and prevented cell growth by about $90 \%$ [52]. Aqueous and alcoholic extractions of Nigella sativa are effective in inactivating a line of breast cancer cells, and have an impact on life span. Those extracts are also useful for treating for breast cancer $[52,59]$. Reduction of damage to DNA and inhibition of carcinogenesis in colon tissues can be done by Nigella sativa that are exposed to toxic agents. A study assessing the relationship between Nigella sativa and colon cancer showed that thymoquinone inhibits 5lipoxygenase products such as 5-hydroxeicosatetraenoic acids needed for colon cancer cells [60]. In a study conducted on male albino rats found that Nigella sativa seed, oil, and thymoquinone are much effective against toxicity induced by the anticancer drug cyclophosphamide and Nigella sativa can be used as appreciative anticancer therapy to reduce long-term chemotherapy side effects [61].

\section{BENEFITS OF Nigella sativa FOR TREATING MOST COMMON COMMUNICABLE DISEASES Effects on the outcome of hepatitis $\mathrm{C}$ virus (HCV) infection}

About 170 million people are infected by hepatitis $\mathrm{C}$ virus ( $\mathrm{HCV}$ ) globally and thus are identified as a viral pandemic five times more severe than human immunodeficiency (HIV-1) infection with type 1 [62]. Nigella sativa's antioxidant effects have been demonstrated in the essential oil extracted from six separate extracts of its seeds, as well as from a commercial fixed oil [67]. The formulation of Nigella sativa seeds significantly inhibited $\mathrm{HCV}$ replication and thus has potential for a novel antiviral agent against HCV infection[63]. The crude Nigella sativa oil and its fragments have exhibited active scavenging activity in vitro[64].

\section{Effect of Nigella sativa on AIDS}

Several million people have been living with this terrible virus since the 1980s, when the human immunodeficiency virus (HIV) was isolated from patients with bacterial infection and Kaposi sarcoma [65]. All efforts to cure the HIV infection proved abortive while progress was made in regulating almost all the steps involved in the viral replication process [66]. Several herbal medicines played various roles in HIV/AIDS diagnosis, ranging from bacterial infections to viral replication inhibition $[67,68]$. Nigella sativa concoction is likely to be virucidal because the viral load dramatically decreased and the symptoms and signs associated with HIV infection disappeared following a drop in CD4 counts in this patient at the early stage of treatment [69]. This is supported by earlier studies in which Nigella sativa and protease inhibitors preferentially lyse viral infected cells [70].

\section{Effect of Nigella sativa on Malaria}

Malaria is the most common infectious tropical disease in the worldwide which is caused by protozoan parasites from Plasmodium genus [71]. Every year more than one million people died and 300500 million people are being infected due to malaria, with extremely high fatality rates among young children below 5 years of age [72]. Many types of herbs or traditional plants have been recognized and used worldwide for having anti-malarial properties to treat malaria. The $N$. sativa seeds which is known to include many medicinal properties particularly in GrecoArab/Unani-Tibb and Ayurveda system of medicine, have a great medicinal importance [73, 74]. Several studies documented the anti-malarial effects of Nigella sativa seeds [75-77]. The anti-malarial activities exhibited by those extracts were perhaps due to the possible presence of active compounds [75]. It was believed that different types of alkaloids [78] from the $N$ sativa seeds extraction can block protein synthesis in Plasmodium falciparum[79] and also contain phenolic compound[80]. These molecules are well known for their diverse physiological properties, including among others, anticarcinogenic, anti-inflammatory and antiparasitic [81]. The anti-oxidant effect of the $N$. sativa oil and its components may represent another mechanism that contributes to its anti-malarial activity [75].

\section{Antifungal effect}

The antibacterial activities of total extracts and essential oils of Nigella sativa seeds have been studied in mice [82, 83]. Negilla sativa crude extract had a positive impact on the candida albicans fungus [84].The Nigella sativa seeds aqueous extract displays an inhibitory activity against candidiasis and the research validates the plant 's traditional use in fungal infections [85]. Eight dermatophytes were screened against antifungul activities of Nigella sativa extract and its active thymoquinone concept: four species of Trichophyton rubrum and one species of Trichophyton interdigitale, Trichophyton mentagrophytes, Epidermophytonfloccosum and Microsporumcanis [86].

\section{CONCLUSION}

Traditional medicinal plants have received a lot of attention because of many factors like low price, easy access, and lower adverse effect profiles as compared to artificial medicines. Among numerous plants, black cumin has been utilized by diverse human cultures around the world particularly in Muslim population for hundreds of years to treat various ailments. To date, variety of reports showed that Nigella sativa and its part as well as thymoquinone have revealed a remarkable natural therapy for treatment of a huge range of diseases as well as noncommunicable diseases (hypertension, diabetes, cardiovascular disease, obesity, cancer, etc.) and communicable diseases (malaria, AIDS, HCV, fungal, viral, and parasitic infections). Both animal and human studies additionally showed that Nigella sativa (black seed) and thymoquinone have potential to treat many diseases and their antioxidant activities have recently 
gained bigger attention because of their role as dietary supplements with marginal side effects. However, most of the other effects and applications of Nigella sativa need further clinical and animal studies.

\section{REFERENCES}

1. Dubick, M. A. (1986). Historical perspectives on the use of herbal preparations to promote health. The Journal of Nutrition, 116(7), 13481354.

2. Paarakh, P. M. (2010). Nigella sativa Linn.-A comprehensive review.

3. Kharelep, C. P. (2004). Encyclopedia of Indian Medicinal Plants (Regional Western Therapy Ayurvedic and Other Traditional Usage, Botany).

4. Al-Bukhari, M. I., \& Sahi, A. B. (1976). The collection of authentic sayings of Prophet Mohammad (peace be upon him), division 71 on medicine. Hilal Yayinlari, Ankara, Turkey.

5. Razavi, B. M., \& Hosseinzadeh, H. (2014). A review of the effects of Nigella sativa $\mathrm{L}$. and its constituent, thymoquinone, in metabolic syndrome. Journal of Endocrinological Investigation, 37(11), 1031-1040.

6. Kar, Y. (2008). The Investigation of Black cumin (Nigella sativa L.) seed as the resource of natural antioxidant and alternative energy (Doctoral dissertation, Ph. D. Thesis, Selcuk University Graduate School of Natural and Applied Sciences, Department of Chemistry, Konya, Turkey).

7. Sharma, P. C., Yelne, M. B., \& Dennis, T. J. (2005). Database on medicinal plants used in Ayurveda (Vol. 3, pp. 130-131). New Delhi: CCRAS.

8. Entok, E., Ustuner, M. C., Ozbayer, C., Tekin, N., Akyuz, F., Yangi, B., ... \& Gunes, H. V. (2014). Anti-inflammatuar and anti-oxidative effects of Nigella sativa L.: 18 FDG-PET imaging of inflammation. Molecular biology reports, 41(5), 2827-2834.

9. Goreja, W. G. (2003). Black seed: nature's miracle remedy. Karger Publishers.

10. Al-Ali, A., Alkhawajah, A. A., Randhawa, M. A., \& Shaikh, N. A. (2008). Oral and intraperitoneal LD50 of thymoquinone, an active principle of Nigella sativa, in mice and rats. J Ayub Med Coll Abbottabad, 20(2), 25-27.

11. Warrier, P. K. (1993). Indian medicinal plants: a compendium of 500 species (Vol. 5). Orient Blackswan.

12. Al-Jassir, M. S. (1992). Chemical composition and microflora of black cumin (Nigella sativa L.) seeds growing in Saudi Arabia. Food Chemistry, 45(4), 239-242.

13. Malik, S., Hasan, S. S., Choudhary, M. I., Ni, C. Z., \& Clardy, J. (1995). Nigellidine-a new indazole alkaloid from the seeds of Nigella sativa. Tetrahedron letters, 36(12), 1993-1996.

14. Ebru, U., Burak, U., Yusuf, S., Reyhan, B., Arif, K., Faruk, T. H., ... \& Kemal, E. (2008).
Cardioprotective effects of Nigella sativa oil on cyclosporine A- induced cardiotoxicity in rats. Basic \& clinical pharmacology \& toxicology, 103(6), 574-580.

15. Mahdavi, R., Namazi, N., Alizadeh, M., \& Farajnia, S. (2015). Effects of Nigella sativa oil with a lowcalorie diet on cardiometabolic risk factors in obese women: a randomized controlled clinical trial. Food \& function, 6(6), 2041-2048.

16. Ahmed, M. A., \& Hassanein, K. M. (2013). Cardio protective effects of Nigella sativa oil on lead induced cardio toxicity: Anti inflammatory and antioxidant mechanism. Journal of Physiology and Pathophysiology, 4(5), 72-80.

17. Zaoui, A., Cherrah, Y., Lacaille-Dubois, M. A., Settaf, A., Amarouch, H., \& Hassar, M. (2000). Diuretic and hypotensive effects of Nigella sativa on the spontaneously hypertensive rat. Therapie, 55(3), 379-382.

18. Hassanin, N. I., \& Hassan, F. M. (1996). A preliminary study on the effect of Nigella sativa seeds on hypoglycemia. Vet Med J Giza, 44, 699 . 708 .

19. Boskabady, M. H., Shafei, M. N., \& Parsaee, H. (2005). Effects of aqueous and macerated extracts from Nigella sativa on guinea pig isolated heart activity. Die Pharmazie-An International Journal of Pharmaceutical Sciences, 60(12), 943-948.

20. Nair, S. C., Salomi, M. J., Panikkae, B., \& Panikkar, K. R. (1991). Modulatory effects of Crocus sativus and Nigella sativa extracts on cisplatin-induced toxicity in mice. Journal of ethnopharmacology, 31(1), 75-83.

21. Bamosa, A., Ali, B. A., \& Al-Hawsawi, Z. A. (2002). The effect of thymoquinone on blood lipids in rats. Indian journal of physiology and pharmacology, 46(2), 195-201.

22. Mahfouz, M., \& El-Dakhakhny, M. (1960). Chemical and pharmacological properties of the new anti-asthmatic drug, nigellone. Egypt Pharm Bull, 42(4), 1-424.

23. El Tahir, K. E., Ashour, M. M., \& Al-Harbi, M. M. (1993). The cardiovascular actions of the volatile oil of the black seed (Nigella sativa) in rats: elucidation of the mechanism of action. General Pharmacology: The Vascular System, 24(5), 11231131.

24. Domanski, M., Mitchell, G., Pfeffer, M., Neaton, J. D., Norman, J., Svendsen, K., ... \& MRFIT Research Group. (2002). Pulse pressure and cardiovascular disease-related mortality: follow-up study of the Multiple Risk Factor Intervention Trial (MRFIT). Jama, 287(20), 2677-2683.

25. Whelton, P. K., He, J., Appel, L. J., Cutler, J. A., Havas, S., Kotchen, T. A., ... \& Karimbakas, J. (2002). Primary prevention of hypertension: clinical and public health advisory from The National High Blood Pressure Education Program. Jama, 288(15), 1882-1888. 
26. Whelton, P.K., R.M. Carey., \& Aronow, W.S. (2018).

Acc/aha/aapa/abc/acpm/ags/APhA/ASH/ASPC/nm $\mathrm{a} /$ pcna guideline for the prevention, Detection, evaluation, and management of high blood pressure in adults: a Report of the American College of Cardiology/American heart Association. Task force on clinical practice guidelines//J. Am. Coll. Cardiol.-2017.-Nov 13. Почки, 7(1).

27. Mathur, M. L., Gaur, J., Sharma, R., \& Haldiya, K. R. (2011). Antidiabetic properties of a spice plant Nigella sativa. Journal of Endocrinology and Metabolism, 1(1), 1-8.

28. Nader, M. A., El-Agamy, D. S., \& Suddek, G. M. (2010). Protective effects of propolis and thymoquinone on development of atherosclerosis in cholesterol-fed rabbits. Archives of Pharmacal Research, 33(4), 637-643.

29. Ahmad, A., Husain, A., Mujeeb, M., Khan, S. A., Najmi, A. K., Siddique, N. A., ... \& Anwar, F. (2013). A review on therapeutic potential of Nigella sativa: A miracle herb. Asian Pacific journal of tropical biomedicine, 3(5), 337-352.

30. Keyhanmanesh, R., Gholamnezhad, Z., \& Boskabady, M. H. (2014). The relaxant effect of Nigella sativa on smooth muscles, its possible mechanisms and clinical applications. Iranian journal of basic medical sciences, 17(12), 939.

31. Dehkordi, F. R., \& Kamkhah, A. F. (2008). Antihypertensive effect of Nigella sativa seed extract in patients with mild hypertension. Fundamental \& clinical pharmacology, 22(4), 447-452.

32. Leong, X. F., Rais Mustafa, M., \& Jaarin, K. (2013). Nigella sativa and its protective role in oxidative stress and hypertension. Evidence-Based Complementary and Alternative Medicine, 2013.

33. Grundy, S.M. (2000). Metabolic complications of obesity. Endocrine, 13(2), 155-165.

34. Pi-Sunyer, F.X. (2002). The medical risks of obesity. Obesity Surgery, 12(1), S6-S11.

35. Stevens, J., Cai, J., Evenson, K. R., \& Thomas, R. (2002). Fitness and fatness as predictors of mortality from all causes and from cardiovascular disease in men and women in the lipid research clinics study. American journal of epidemiology, 156(9), 832-841.

36. Hasani-Ranjbar, S., Jouyandeh, Z., \& Abdollahi, M. (2013). A systematic review of anti-obesity medicinal plants-an update. Journal of Diabetes \& Metabolic Disorders, 12(1), 28.

37. Vanamala, J., Kester, A. C., Heuberger, A. L., \& Reddivari, L. (2012). Mitigation of obesitypromoted diseases by Nigella sativa and thymoquinone. Plant foods for human nutrition, 67(2), 111-119.

38. Bamosa, A. O., Kaatabi, H., Lebdaa, F. M., Elq, A. M., \& Al-Sultanb, A. (2010). Effect of Nigella sativa seeds on the glycemic control of patients with type 2 diabetes mellitus. Indian J Physiol Pharmacol, 54(4), 344-54.

39. Datau, E. A., Surachmanto, E. E., Pandelaki, K., \& Langi, J. A. (2010). Efficacy of Nigella sativa on serum free testosterone and metabolic disturbances in central obese male. Acta Medica Indonesiana, 42(3), 130-134.

40. Qidwai, W., Hamza, H. B., Qureshi, R., \& Gilani, A. (2009). Effectiveness, safety, and tolerability of powdered Nigella sativa (kalonji) seed in capsules on serum lipid levels, blood sugar, blood pressure, and body weight in adults: results of a randomized, double-blind controlled trial. The Journal of alternative and complementary medicine, 15(6), 639-644.

41. de Vegt, F., Dekker, J. M., Jager, A., Hienkens, E., Kostense, P. J., Stehouwer, C. D., ... \& Heine, R. J. (2001). Relation of impaired fasting and postload glucose with incident type 2 diabetes in a Dutch population: The Hoorn Study. Jama, 285(16), 2109-2113.

42. Heshmati, J., Namazi, N., Memarzadeh, M. R., Taghizadeh, M., \& Kolahdooz, F. (2015). Nigella sativa oil affects glucose metabolism and lipid concentrations in patients with type 2 diabetes: A ra

43. Benhaddou-Andaloussi, A., Martineau, L. C., Spoor, D., Vuong, T., Leduc, C., Joly, E., ... \& Prentki, M. (2008). Antidiabetic activity of Nigella sativa. Seed extract in cultured pancreatic $\beta$-cells, skeletal muscle cells, and adipocytes. Pharmaceutical Biology, 46(1-2), 96104.

44. Kaatabi, H., Bamosa, A. O., Badar, A., Al-Elq, A., Abou-Hozaifa, B., Lebda, F., ... \& Al-Almaie, S. (2015). Nigella sativa improves glycemic control and ameliorates oxidative stress in patients with type 2 diabetes mellitus: placebo controlled participant blinded clinical trial. PloS one, 10(2), e0113486.

45. El-Dakhakhny, M., Mady, N., Lembert, N., \& Ammon, H. P. T. (2002). The hypoglycemic effect of Nigella sativa oil is mediated by extrapancreatic actions. Planta medica, 68(05), 465-466.

46. Fararh, K. M., Atoji, Y., Shimizu, Y., Shiina, T., Nikami, H., \& Takewaki, T. (2004). Mechanisms of the hypoglycaemic and immunopotentiating effects of Nigella sativa L. oil in streptozotocininduced diabetic hamsters. Research in veterinary science, 77(2), 123-129.

47. Bamosa, A. O. (2015). A review on the hypoglycemic effect of Nigella sativa and thymoquinone. Saudi Journal of Medicine and Medical Sciences, 3(1), 2.

48. El-Dakhakhny, M., Barakat, M., Abd El-Halim, M., \& Aly, S. M. (2000). Effects of Nigella sativa oil on gastric secretion and ethanol induced ulcer in rats. Journal of ethnopharmacology, 72(1-2), 299304. 
49. Bamosa, A. O., Ali, B. A., \& Sowayan, S. A. (1997). Effect of oral ingestion Nigella sativa seeds on some blood parameters. Saudi Pharmaceutical Journal, 5, 126-129.

50. Grundy, S. M. (1991). Recent nutrition research: implications for foods of the future. Annals of medicine, 23(2), 187-193.

51. Khan, A., Chen, H. C., Tania, M., \& Zhang, D. Z. (2011). Anticancer activities of Nigella sativa (black cumin). African Journal of Traditional, Complementary and Alternative Medicines, 8(5S).

52. Hammad Shafiq, A. A., Masud, T., \& Kaleem, M. (2014). Cardio-protective and anti-cancer therapeutic potential of Nigella sativa. Iranian journal of basic medical sciences, 17(12), 967.

53. Badary, O. A., Taha, R. A., Gamal El-Din, A. M., \& Abdel-Wahab, M. H. (2003). Thymoquinone is a potent superoxide anion scavenger. Drug and chemical toxicology, 26(2), 87-98.

54. Khader, M., Bresgen, N., \& Eckl, P. M. (2010). Antimutagenic effects of ethanolic extracts from selected Palestinian medicinal plants. Journal of ethnopharmacology, 127(2), 319-324.

55. Randhawa, M. A., \& Alghamdi, M. S. (2011). Anticancer activity of Nigella sativa (black seed)a review. The American journal of Chinese medicine, 39(06), 1075-1091.

56. El-Kadi, A., \& Kandil, O. (1986, November). Effect of Nigella sativa (the black seed) on immunity. In Proceeding of the 4th International Conference on Islamic Medicine, Kuwait. Bull Islamic Med (Vol. 4, pp. 344-8).

57. Badary, O. A., Nagi, M. N., Al-Shabanah, O. A., Al-Sawaf, H. A., Al-Sohaibani, M. O., \& AlBekairi, A. M. (1997). Thymoquinone ameliorates the nephrotoxicity induced by cisplatin in rodents and potentiates its antitumor activity. Canadian journal of physiology and pharmacology, 75(12), 1356-1361.

58. Rooney, S., \& Ryan, M. F. (2005). Modes of action of alpha-hederin and thymoquinone, active constituents of Nigella sativa, against HEp-2 cancer cells. Anticancer research, 25(6B), 42554259.

59. Farah, I. O., \& Begum, R. A. (2003). Effect of Nigella sativa (N. sativa L.) and oxidative stress on the survival pattern of MCF-7 breast cancer cells. Biomedical Sciences Instrumentation, 39, 359-364.

60. El-Mahmoudy, A., Matsuyama, H., Borgan, M. A., Shimizu, Y., El-Sayed, M. G., Minamoto, N., \& Takewaki, T. (2002). Thymoquinone suppresses expression of inducible nitric oxide synthase in rat macrophages. International immunopharmacology, 2(11), 1603-1611.

61. Alenzi, F. Q., El-Bolkiny, Y. E. S., \& Salem, M. L. (2010). Protective effects of Nigella sativa oil and thymoquinone against toxicity induced by the anticancer drug cyclophosphamide. British journal of biomedical science, 67(1), 20-28.
62. Lauer, G. M., \& Walker, B. D. (2001). Hepatitis C virus infection. New England journal of medicine, 345(1), 41-52.

63. Oyero, O. G., Toyama, M., Mitsuhiro, N., Onifade, A. A., Hidaka, A., Okamoto, M., \& Baba, M. (2016). Selective inhibition of hepatitis c virus replication by Alpha-zam, a Nigella sativa seed formulation. African journal of traditional, complementary and alternative medicines, 13(6), 144-148.

64. Ramadan, M. F., Kroh, L. W., \& Mörsel, J. T. (2003). Radical scavenging activity of black cumin (Nigella sativa L.), coriander (Coriandrum sativum L.), and niger (Guizotia abyssinica Cass.) crude seed oils and oil fractions. Journal of agricultural and food chemistry, 51(24), 6961-6969.

65. Barré-Sinoussi, F., Chermann, J. C., Rey, F., Nugeyre, M. T., Chamaret, S., Gruest, J., ... \& Rozenbaum, W. (1983). Isolation of a Tlymphotropic retrovirus from a patient at risk for acquired immune deficiency syndrome (AIDS). Science, 220(4599), 868-871.

66. Kindt, T. J., Goldsby, R. A., Osborne, B. A., \& Kuby, J. (2007). Kuby immunology. Macmillan.

67. Vlietinck, A. J., De Bruyne, T., Apers, S., \& Pieters, L. A. (1998). Plant-derived leading compounds for chemotherapy of human immunodeficiency virus (HIV) infection. Planta medica, 64(02), 97-109.

68. Kong, J. M., Goh, N. K., Chia, L. S., \& Chia, T. F. (2003). Recent advances in traditional plant drugs and orchids. Acta Pharmacologica Sinica, 24(1), 721.

69. Onifade, A. A., Jewell, A. P., \& Adedeji, W. A. (2013). Nigella sativa concoction induced sustained seroreversion in HIV patient. African Journal of Traditional, Complementary and Alternative Medicines, 10(5), 332-335.

70. Levin, A., Hayouka, Z., Friedler, A., \& Loyter, A. (2010). Specific eradication of HIV-1 from infected cultured cells. AIDS Research and Therapy, 7(1), 1-5.

71. Breman, J. G. (2001). The ears of the hippopotamus: manifestations, determinants, and estimates of the malaria burden. The American journal of tropical medicine and hygiene, 64(1_suppl), 1-11.

72. Malaria, R. B. (2005). World malaria report 2005. World Health Organization and UNICEF.

73. Asolkar, L. V., \& Chopra, R. N. (1992). Second supplement to glossary of Indian medicinal plants with active principles. Publications \& Information Directorate.

74. Salem, M. L. (2005). Immunomodulatory and therapeutic properties of the Nigella sativa L. seed. International immunopharmacology, 5(1314), 1749-1770.

75. Abdulelah, H. A. A., \& Zainal-Abidin, B. A. H. (2007). In vivo anti-malarial tests of Nigella sativa 
(black seed) different extracts. Am J Pharmacol Toxicol, 2(2), 46-50.

76. Sosiawan, T. I., Linda, W., \& Etty, W. (2013). Anti-Malaria Study of Nigella sativa L. Seed Water Extract in Mus musculus Mice Balb C Strain In Vivo. Makara Journal of Science, 192-196.

77. Ashcroft, O. F., Salaudeen, O. F., Mohammed, K., Spencer, T. H. I., Garba, M. K., Nataala, S. U., \& Iduh, U. M. (2018). Anti-malarial effect of Nigella sativa seeds (black seed) extract on mice infected with Plasmodium bergei (nk 65). European Journal of Pharmaceutical and Medical Research, 5(10), 131-137.

78. Malik, S., Cun-Heng, H., \& Clardy, J. (1985). Isolation and structure determination of nigellicine, a novel alkaloid from the seeds of Nigella sativa. Tetrahedron letters, 26(23), 2759-2762.

79. Elford, B. C. (1986). L-Glutamine influx in malaria-infected erythrocytes: a target for antimalarials?. Parasitology Today, 2(11), 309-312.

80. Nergiz, C., \& Ötleş, S. (1993). Chemical composition of Nigella sativa L. seeds. Food chemistry, 48(3), 259-261.

81. Ma, Q., \& Kinneer, K. (2002). Chemoprotection by Phenolic Antioxidants Inhibition of Tumor Necrosis Factor A Induction In
Macrophages. Journal of Biological Chemistry, 277(4), 2477-2484.

82. Hosseinzadeh, H., Fazly Bazzaz, B. S., \& Haghi, M. M. (2007). Antibacterial activity of total extracts and essential oil of Nigella sativa L. seeds in mice. Pharmacologyonline, 2, 429-435.

83. Entela, H., Stefano, M., Vilma, T., \& Silvia, V. (2012). Antimicrobial and antifungal activity assesment of Nigella sativa essential oils.

84. Mashhadian, N. V., \& Rakhshandeh, H. (2005). Antibacterial and antifungal effects of Nigella sativa extracts against $\mathrm{S}$. aureus, $\mathrm{P}$. aeroginosa and C. albicans. Pak J Med Sci, 21(1), 47-52.

85. Khan, M. A. U., Ashfaq, M. K., Zuberi, H. S., Mahmood, M. S., \& Gilani, A. H. (2003). The in vivo antifungal activity of the aqueous extract from Nigella sativa seeds. Phytotherapy Research: An International Journal Devoted to Pharmacological and Toxicological Evaluation of Natural Product Derivatives, 17(2), 183-186.

86. Aljabre, S. H. M., Randhawa, M. A., Akhtar, N., Alakloby, O. M., Alqurashi, A. M., \& Aldossary, A. (2005). Antidermatophyte activity of ether extract of Nigella sativa and its active principle, thymoquinone. Journal Ethnopharmacology, 101(1-3), 116-119. 